\title{
Discource on Students' Participation in International Projects on Inter-Ethnic Tolerance Formation in Multicultural Environment
}

\author{
Tatiana M. Tregubova, Vadim E. Kozlov \\ and Alexandra S. Kats* \\ Institute of Pedagogy, Psychology and Social Problems \\ 12 Isaeva Str., Kazan, 420039, Republic of Tatarstan, Russia
}

Received 28.12.2018, received in revised form 21.01.2019, accepted 06.02.2019

The article aims at clarifying whether international educational projects offer a real assistance in developing the students' personal, spiritual and moral qualities such as interethnic tolerance as well as at analyzing the character, dynamics, and direction of interethnic communication. From the standpoint of pedagogy, international projects are viewed as an opportunity to show an individual's ethnicity in professional and interpersonal spheres and a step forward to interethnic interaction based on international cooperation. The results of the empirical research prove efficiency and productivity of international projects as a powerful mechanism of personal growth, development, and self-perfection. They also make it possible to trace the perspective ways of development of interethnic cooperation between Russia and its European partners in the educational sphere. To sum up, international projects enhance teaching and learning opportunities, enlarge the sphere of professional and interpersonal communication, and provide a real support in the production of a new type of specialist - a person with a planetary way of thinking, able to work and study in a multicultural educational environment, flexible and ready for dynamic changes in a globalizing world.

Keywords: international educational project, international cooperation, ethnicity, ethnic group, multicultural educational environment.

Research area: education, pedagogy.

Citation: Tregubova, T.M., Kozlov, V.E, Kats, A.S. (2019). Discource on students' participation in international projects on inter-ethnic tolerance formation in multicultural environment. J. Sib. Fed. Univ. Humanit. soc. sci., 12(2), 261-274. DOI: 10.17516/1997-1370-0393.

(C) Siberian Federal University. All rights reserved

* Corresponding author E-mail address: tmtreg@mail.ru; vadim.kozlov@list.ru; cats.schura@yandex.ru ORCID: 0000-0001-9938-0098 (Tatiana Tregubova); 0000-0002-2735-8251 (Alexandra Kats)

This work is licensed under a Creative Commons Attribution-NonCommercial 4.0 International License (CC BY-NC 4.0). 


\section{Introduction}

Actuality of international educational projects and programmes on tolerance formation are determined by the phenomena of internationalization and international educational integration as a global vision. Yet, if taking a close shot, as O. Smolyaninova suggests, "In modern multinational Russia, the territory of which is inhabited by 190 nations, the urgent problem is the increasing number of ethnic conflicts among young people". This disintegrates and disunites modern Russian society (Smolyaninova, Trufanov, 2018). We suppose that internationalization is a transition into a completely new educational level, on which all actions of the partner countries are of an international character and, therefore, become socially valuable and vitally important for a multicultural society. Modern socio-economic situation in Russia presupposes that the majority of Russian universities tend to cooperate with the best educational institutions of Europe and the USA. Internationalization of Russian education includes such aspects as student and professor mobility, co-work on educational programmes, plans and modules, taking into account perspective European experience, orientation towards intercultural education, and co-evaluation of students' results with the help of ECTS.

Internationalization stimulates the development of such personal qualities as interethnic tolerance which implies humanity, kind-heartedness, and communicativeness. The degree of involvement into the international project activity, first of all, increases a future specialist's ability to compete in the professional sphere. Besides, it stimulates cooperation between partner universities, cooperation being based on mutual understanding and equality in rights. According to I. Grebeniuk, "the model of global research university has become widespread with the universities as productive actors not only in producing knowledge but in its dissemination" (Grebeniuk et al., 2012).

Practical importance of international educational projects is revealed in the opportunity to form a new generation of young scientists and provide free access to research co-work in the sphere of education. Participation in an international educational project is a possibility to enlarge the scientific sphere of an individual's activity and interpersonal relations. Secondly, multicultural educational environment, which favours the process of co-work in research and creative activity, positively influences the working and academic atmosphere of international cooperation. Thirdly, participation in an international process is a key condition of the intercultural competence formation. Finally, via international project activity a person acquires major professional competences, necessary for the realization of academic, professional, and creative activity. Qualified specialists who are constantly improving in the process of intercultural professional 
communication and developing themselves and their relations through the dialogue of cultures is a predictive result of the international projects functioning. Subsequently, the results of the international project activity can be understood as the results of international cooperation aimed at co-working in research.

A. Khutorskoi introduces his own conception of competences which include value, general cultural, learning and cognitive, informational, communicative, social and labour ones as well as the specific competences of self-improvement (Khutorskoi, 2007). The author emphasizes that the formation of this list of competences is based, first of all, on the realization of goal and tasks of modern educational system and on the types of cognitive activity of the learner who is supposed to acquire positive vital and social experience, abilities to cooperate in a multicultural society. International project activity presupposes that the main competence is a communicative one as it stimulates interethnic interaction. R. Sagitova states that "communicative abilities are oriented towards creation of a positive psychological climate stimulating self-development and creative activity of the participants of the educational process" (Sagitova, 2017).

\section{Methodological framework}

The methodological framework of this research rests on the competence approach, which becomes especially sufficient for inter-personal and professional communication and working in the conditions of a multicultural society. The comparative analysis of the research works (Khutorskoi, 2007; Sagitova, 2017; Tregubova, 2016) shows that the most valuable and important competence for the international project activity organization is supposed to be the intercultural as it includes skills and abilities, necessary for coliving of people of different confessions and nationalities. However, it has gradually become a characteristic feature of the whole educational process. The intercultural competence includes the following aspects: the ability to work in a multi-disciplinary team with mixed ethnic body structure; the ability to understand and accept ethnic and cultural diversity; the ability to participate and organize international projects and programmes; and the ability to hold on various moral and ethnic values (Gorilev et al., 2011). This competence is aimed at achieving the humans' success and well-being as well as at perfecting their spiritual and moral features. The formation of the mentioned above competence helps much in developing the personality's abilities, necessary for co-living and co-working in a multicultural educational environment.

Subsequently, international educational projects unite different people in their common professional, creative, or academic activities. These activities are realized in the 
course of interpersonal and professional communication based on interethnic tolerance. People, working in a multi-disciplinary team, tend to overcome communicative barriers of their ethnos and become individuals with a planetary way of thinking. The ability to accept cultural diversity is necessary for the comparative analysis of different cultures, based on the acceptance of other moral and ethnic values. The ability to participate in international projects shows that a person is striving to be integrated in a multicultural society. The ability to accept different important values presupposes a conscious choice of tolerance as an instrument of resistance to aggression and violence. The pedagogues' orientation towards the key competences formation defines not only a developed culture system but also a desire for international educational integration that is highly appreciated in modern Russian society.

The international experience in the sphere of international cooperation is reflected in the works of a number of scholars (Arganova, 2011; Danilkina, 2015; Firsova, 2011; Garskov, 2012; Malov et al., 2010; Zainieva et al., 2015, Ziuban, 2014). The works devoted to an intricate issue of international educational projects are thoroughly examined by the following authors: Grigorev et al. (2016); Kersh et al. (2015); McKinney (2017); Morova (2017); Morova et al. (2015); Mukhametzianova \& Tregubova (2017); Tregubova (2015); Zannoni \& Kostrov (2017).

The experimental part of our research was devoted to the analysis of the current state of interethnic tolerance formation. The basic institutions for the experimental research were ASE (Academy of Social Education) and Gymnasium 122 named after Zh. Zaitseva in Kazan. The goal of our experimental work was to increase the level of the intercultural competence by implementing the various forms and methods of social-creative activities such as round table discussions, debates, panel discussions, conferences, etc. aimed at involving the students into interethnic interaction. The conducted analysis enabled us to define the actual problems connected with the tolerance formation and to determine the perspectives of its development in a multicultural educational environment.

\section{Results}

In the course of the project implementation we were constantly introducing, collecting and systemizing the information from the two experimental platforms ASE (Academy of Social Education) and Gymnasium 122 named after Zh. Zaitseva. Together with the Institute's staff we developed the "Multi-cultural education and tolerance formation in Russia" course. While mastering it "the pedagogues were 
taught to interact effectively with the representatives of other ethnic groups, thus, developing their communicative skills in the student body" (ALLMEET, 2016). To report its functioning we developed and tested a series of learning and educating activities for students and schoolchildren. These were 1) "Tolerance is the way to the dialogue of cultures" training; 2) "To be tolerant is to live in harmony with oneself and others" training; 3) "Greeting", "Verbal portrait", "Our group", "White raven" and other organizational games (Kats, 2017). Historical data about the interethnic tolerance formation in the gymnasium and the academy were presented in the form of learning, creative and educational activities. We also managed to adopt the "Index of Tolerance" questionnaire (Soldatova et al., 2008). The presentations on the most up-to-date and typical problems of tolerance formation were also introduced. The quotation from the report ("When you humiliate somebody some part of yourself must be humiliated and it won't give you the right to realize yourself" (ALLMEET, 2016)) reveals the essence of being tolerant. The report contains the "Evaluation Form" reflecting the course efficiency and productivity. There is also the Reference Literature on the project in the end of our report. It is for the users to refer to the Russian and foreign authors listed.

A considerable part of our research was devoted to the translation and comparative analysis of most professionally valuable articles in the English language. The content of the articles was close to the topic of our research and focused on the tolerance formation in a multicultural region. Some of the articles were included in the collective monograph published by the scientific staff of the Institute. It was found out that in Bologna there are two types of integrative policies: the multicultural model which implies the immigrants' inclusion in the overall social and political structure and the assimilative model which is characterized by an individual approach towards immigrants. Respectively, according to M. Cuconato, "a special attention should be paid to the policy of support for intercultural education, mediation in the society and immigrants' participation in management of social sphere" (Mukhametzianova et al., 2017). It is worth while noting that the government's immigration policy may be viewed as multiculturalism in the aspect of creating positive relations with the foreigners who come to Bologna.

\section{Discussions}

The role of international project activity

The role of international educational projects in the interethnic tolerance formation has always been significant. With the help of a series of activities, organized especially 
for the project, such as interactive and practical lessons, seminars, lessons of travelling, discussions, debates, etc. the students learn an ethnic group's culture, their traditions and customs. Thanks to this knowledge, abilities and skills the intercultural competence is formed. This competence implies the culturological recognition of differences, the development of pride and respect for the nation's unique features, the desire to be ready to interact in the context of socio-cultural transformations in the globalizing world, the involvement in intercultural interaction and in social and political parts of life. The skills and abilities mentioned above seem to be socially and vitally important for intercultural cooperation. So, it gives us the right to speak for free that international educational projects favour the perfection of civil and patriotic system of education, the development of the "culture of tolerance" and its humanistic nature. Participation in such projects is considered to be the best contribution to the formation of a successful multicultural personality who is able to realize him/herself in various spheres of life.

O. Smolyaninova states that "the multiculturalism policy" on a personal level is a result of critical, reflexive and creative way of thinking which considers the society's ethnical diversity traced in a person's desire to establish relations with the people of his/her own culture as well as of "foreign" cultures (Smolyaninova, 2016a). This quotation proves the author's position that the international educational projects are oriented towards intercultural education in the aspect of intercultural relations which are uniquely developed in modern society. Consequently, upbringing and development of a multicultural personality is a constituent task not only for higher education institutions. It should be also realized via international educational projects.

Moreover, international educational projects fulfil other useful options necessary for peaceful co-living in the multicultural reality. T. Tregubova defines them as "strategies of developing complex safety in the sphere of education, expanding the scope of multicultural communication in the university" (Tregubova, 2016), This favours the formation of a man of culture and the intensification of the role of intercultural communication. Due to this the international educational projects are considered to be socially oriented. They contribute to overcoming the society's "illnesses", such as discrimination, racism, terrorism, extremism, and xenophobia. Their public discussion with the students results in the formation of the students' critical thinking. International projects on tolerance formation have become extremely sufficient. According to Olga Smolyaninova, "tolerance is a crucial factor in reducing the acts of violence, discrimination, violation of human rights, and interethnic tensions" (Smolyaninova, 2016b). 
M. Cuconato and T. Tregubova are convinced that "it is intercultural cooperation that is the most decisive factor in the interaction of different nations since success in the professional formation largely depends on the ability to interact with other cultures" (Cuconato \& Tregubova, 2016). Thus, one of the most vital abilities is an ability to create a constructive dialogue of cultures based on their uniqueness and originality.

M. Barrett states that "today there is a real need, that touches upon each aspect of life, especially education, that supports citizens to coexist together in a culturally diverse society" (Barrett et al., 2014). The group of the researchers under his supervision has come to such conclusions because of the current socio-economic situation in the country, the situation reflecting the most urgent problems. These problems are ethnic prejudice, hatred, violence, and aggression. They disunite the society, turning it into weak, intolerant and, as a result, victimizable. Subsequently, in the course of their international project activity the scholars and pedagogues were asked to solve the problem of a personality's intercultural competence formation in the system of intercultural education by the institutions of higher and supplementary education, which was successfully realized in the international educational projects.

\section{Conceptual apparatus: the idea of Tolerance Center}

The analysis of scientific works on the issue (Morova et al., 2015; Mukhametzianova \& Tregubova, 2017; Tregubova, 2015; Zannoni \& Kostrov, 2017) shows the preconditions of the Tolerance Centre formation in the process of the ALLMEET project implementation (Lifelong learning oriented towards multicultural education and tolerance formation in Russia) (http://www.allmeet.org/ru/). These are globalization and migration processes; level, character and direction of public relations ensuring the stability in the region as well as intensifying inter- and outer-state migration which are characteristic features of the Republic of Tatarstan, a region with mixed ethnic body structure.

O. Smolyaninova defines the actuality of the Tolerance Center creation as follows: "Sometimes a dispute between students of different nationalities is transformed into interethnic conflict between the participants and their environment, the conflict supported by the media and politicians". In such situation the Tolerance Center is of real help in the interethnic interaction (Smolyaninova, 2018). The Center was established by the scientific staff of the Federal State Budget Scientific Institution "Institute of Pedagogy, Psychology and Social Problems". The Institute is considered to be a linking part between schoolchildren, students and adults, the fact making it actual and up- 
to-date for all ages. According to F. Mukhametzianova and E. Kostrov, "The mission of the center is creation of the system of scientific and methodological support to the formation and development of international and interconfessional solidarity in a multicultural educational environment in Russia" (Mukhametzianova, Cuconato et al., 2017). With our participation the scientific staff of the University have developed and implemented the algorithm of setting up such tolerance centers:

- Stage 1: methodological and organizational. This stage is suitable for developing the theoretical and methodological bases of the project, for defining physical and virtual space for its harmonious and efficient functioning, getting the agreement on international cooperation.

- Stage 2: experimental and practical. At this stage it is recommended to develop the working packages for all types of the activities, define target groups, provide methodological support, obtain the consent on educational, cultural and creative work with the target groups.

- Stage 3: systemizing. This is the stage of organizing the experts' activity and getting the partner countries' feedback.

In the course of their studies the students got acquainted with the culture of different nationalities co-living together in peace and harmony on the territory of the Republic of Tatarstan. A special attention was given to various forms and methods of work: trainings, games and discussions, dialogues and debates. The results of the course served the basis for its monitoring, followed by the corrective measures on the content of education. This led to the sufficient modifications of the module.

On the initial stage, the information on some parts of the project was collected and systematized. The Russian and European scholars analyzed the current state of the problem development in their countries. Leading sociologists, pedagogues and politicians were involved in the process. Teaching psychologists conducted the research in schools and universities to determine the general level of tolerance and critical thinking over the problems of tolerance formation.

F. Zannoni and M. Cuconato from the University of Bologna, our foreign partners in ALLMEET project, defined actual problems on the aspect of the intercultural competence formation:

- preserved stereotypes/ethnic prejudices about a certain nation's behavior, which negatively influence the formation of the tolerance towards them;

- non-equal rights of the titular ethnic group and migrants, humiliation of national minorities; 
- concealed cultural and religious conflicts, poisoning interethnic interaction;

- partial absence or difficulty of communication between certain ethnic groups;

- lack of multicultural learning experience in schools and universities (Zannoni, Cuconato et al., 2017).

M. Perotto pointed out at the factors stimulating the human potential development in order to solve the problems on tolerance formation and cultivation via international project activity which is "connected with the necessity of solving problems associated with the phenomenon of ethnicity: migration, assimilation of cultures, deformation of ethnic self-identification, conflicts on religious and national background" (Perotto et al., 2017). These processes considerably complicate the nature of interethnic relations, prevent from the tolerance formation and development, and stimulate the creation of a special ethno-contact situation.

As active ALLMEET project participants we notice the growth of interest to the issue of interethnic tolerance and suggest that the intercultural competence should be considered by the pedagogues as one of the key competence since it reflects the nature and dynamics of interethnic relations in society which are formed on the basis of multicultural educational environment.

\section{Conclusion and recommendations}

International educational projects, first of all, favour the creation of the atmosphere of friendliness and mutual understanding between the partner countries, thus, minimizing mistrust between them. Secondly, as A. Barsukova states, "they are aimed at creating universal conditions under which they act as the collective memory holders, consolidation of the national idea as a structural component with the greatest educational potential and impact on the society's social life" (Barsukova \& Zhukovskii, 2013). These projects are also aimed at direct cooperation with the leading universities of Europe to establish culturological, ethnic, and professional ties between partner countries in order to strengthen their mutual understanding. According to T. Tregubova's scientific view, international cooperation of the universities in the context of international project activities is "a multifunctional and multifaceted means of its strategic development" (Tregubova, 2015). In other words, international educational projects reveal huge stimulating potential for integration processes. They are the main reason for drawing together different cultures and ethnic groups, their vital values, traditions, and educational guidelines. 
International project activity is focused on the formation of key interpersonal competences, including interethnic tolerance as a competence stimulating intercultural communication. These competences are of great cultural value for peaceful co-living in a multicultural society with its interethnic contacts. The competences help to determine the range of the demands for the training of not only highly qualified specialists but also students as future specialists for constructive activities in a multicultural educational environment.

International educational activities stimulate educational and extracurricular activities with the target groups, the students being also a target audience. The content of the article covers the progressive practices of the Federal State Budget Scientific Institution "Institute of Pedagogy, Psychology and Social Problems" as they have made an attempt to systemize the constructive experience on tolerance formation in the Republic of Tatarstan by having realized a series of the activities mentioned. The role of participation in international projects is to create necessary conditions for multicultural education and related activities aimed at achieving a policy of multiculturalism in the Republic of Tatarstan.

\section{References}

ALLMEET (2016). Brief Report for Training Course / Event / Activity-Teaching Materials Description. Kazan: KIPPPE-RAE.

Arganova, I.V. (2011). International Educational Cooperation - Evolution of the Term and Its Content Meaning. In Bulletin of Peoples' Friendship University of Russia, 4, 124-133.

Barrett, M., Byram, M., Lázár, I., Mompoint-Gaillard, P. Philippou, S. (2014). Developing Intercultural Competence Through Education. Strasbourg: Pestalozzi Series, 3, 132.

Barsukova, A.V., Zhukovskii, I.I. (2013). Mezhdunarodnaia deiatel'nost' universitetov (na primere Evropy) [International Activity of the Universities (Case of Europe)]. In MGIMO Review of International Relations, 1 (28), 66-69.

Cuconato, M., Tregubova, T.M. (2016). Rol' mezhdunarodnykh proektov $i$ program $v$ formirovanii grazhdanskoi identichnosti studentov $v$ kontekste sotsiokul'turnykh transformatsii XXI veka [Role of the International Projects and Programs in Formation of Students' Civil Identity in the Context of Sociocultural Transformation in the $21^{\text {st }}$ Century]. In Formirovanie obshcherossiiskoi grazhdanskoi identichnosti kak factor protivodeistviia ideologii ekstremizma v obrazovatel'noi 
srede: materialy Mezhdunarodnoi nauchno-prakticheskoi konferentsii [Formation of All-Russian Civil Identity as a Factor of Resistance to the Ideology of Extremism in the Educational Environment: Proceedings of the International Scientific Conference]. Bologna, 11-17.

Danilkina, A.M. (2015). The International Educational Student Projects is a Tool for Effective Building of Inter-University Cooperation. In Eurasian scientific research, 2, 5(5), 143-145.

Firsova, S.P. (2011). International Cooperation of Higher Educational Institutions in the Context of Pedagogical Research. In The Moscow University Bulletin. Series 20. Pedagogical Education, 1, 76-84.

Garskov, S.N. (2012). Mezhdunarodnoe sotrudnichestvo kak faktor razvitiia sovremennogo vuza $\mathrm{v}$ usloviiakh globalizatsii i internatsionalizatsii obrazovaniia [International Cooperation as a Factor of Modern University Development in the Conditions of Globalization and Integration of Education. In Kazan Pedagogical Journal, 5-6 (95), 63-68.

Gorilev, A.I., Ponomareva, E.A., Rusakov, A.V. (2011). Metodologiia TUNING kompetentnostnyi podkhod pri opredelenii soderzhaniia obrazovatel'nykh programm [TUNING Methodology: Use of the Competence-Based Approach at Determining Study Programs Content]. Nizhny Novgorod, Nizhny Novgorod State University named after N.I. Lobachevski, 46 p.

Grebeniuk, I.I., Golubtsov, N.V., Kozhin, V.A., Chekhov, K.O., Chekhova S.E., Fedorov, O.V. (2012). Analiz innovatsionnoi deiatel'nosti vysshikh uchebnykh zavedenii Rossii [Analysis of Innovative Activity of the Higher Education Institutions in Russia]. Moscow, Akademiia estestvoznaniia, $464 \mathrm{p}$.

Grigorev, S.G., Grinshkun, V.V., Lvova, O.V., Shunina, L.A. (2016). Fostering Tolerance during Life-Long Learning via Means of Informatization. In Bulletin of Peoples' Friendship University of Russia. Series: Informatization in Education, 2, 7-15.

Kats, A. (2017). Mezhetnicheskaia tolerantnost' - put'k garmonii i mezhnatsional'nomu soglasiiu: teoreticheskie i prakticheskie aspekty: obrazovatel'naia programma [Inter-Ethnic Tolerance - the Way to Harmony and Inter-Ethnic Peace: Theoretical and Practical Aspects (Educational Programme)]. Kazan, Pechat'-Servis 21 vek, $60 \mathrm{p}$.

Kersh, N., Kononova, V.A., Obidina, V.V. (2015). Review of Some Recent Life-Long Learning Practices and Models in Russia. In Journal of Siberian Federal University. Humanities \& Social Sciences. Vol. 11 (8), 2195-2200. 
Khutorskoi, A.V. (Ed.). (2007). Kompetentsii v obrazovanii: opyt proektirovaniia: sb. nauch. tr. [Competences in Education: the Experience of Projection: Collection of Proceedings]. M., INEK, 327 p.

Malov, I.V., Krupskaya, T.S., Zobnin, Y.V. (2010). The International Cooperation the Integral Part of Modern Educational Process. In Siberian Medical Journal, 98, 7, 7-9.

McKinney, S., Zannoni, F., Sakaev, V.T. (2017). Problems of Integration of Religious Minorities: Cases of European Union and Russian Federation. In Religious research, 2 (16), 72-107.

Morova, N.S. (2017). Teoriia i praktika polikul'turnogo obrazovaniia: rezul'taty proekta "ALLMEET" programmy TEMPUS [Theory and Practice of Intercultural Education: Results of ALLMEET Project of the TEMPUS Programme]. Krasnoyarsk, Grotesk, $172 \mathrm{p}$.

Morova, N.S., Biryukova, N.A., Lezhnina, L.V., Domracheva, S.A. (2015). Development of Cultural Diversity and Tolerance in a Multi-Ethnic Region: a Case Study of Mari El Republic. In Vestnik of Mari State University, 2, 56-61.

Mukhametzianova, F. Sh., Cuconato, M., Gil'meeva, R.Kh., Kostrov, E.N., Maslennikova, V.Sh., Tregubova, T.M., Shaikhutdinova, G.A., Shibankova, L.A. (2017). Teoriia i Praktika Razvitiia Tolerantnosti Sredstvami Polikul'turnoi Obrazovatel'noi Platformy v Respublike Tatarstan: kollektivnaia monografia [Theory and Practice of Tolerance Development via the Means of the International Educational Platform in the Republic of Tatarstan: collective monography]. Kazan, Pechat'-Servis 21 vek, $109 \mathrm{p}$.

Mukhametzianova, F.Sh., Tregubova, T.M. (2017). Formirovanie tolerantnoi lichnosti v kul'turno-obrazovatel'nom prostranstve regionov Rossii i za rubezhom: rol' mezhdunarodnykh proektov [Formation of Tolerant Personality in Cultural and Educational Space of Russian Regions and Abroad: the Role of International Projects], In Humanitarian Sciences, 4 (40), 126-132.

Perotto, M., Mustaphina, G., Aitdinov, E. (2017). Theory and Practice of Tolerance Development by Means of Multi-Cultural Educational Programme of Kazan Federal University: monograph. Arkhangelsk, Publishing House named after V.N. Bulatov, 78.

Sagitova, R.R. (2017). Formirovanie samoobrazovatel'noi kompetentsii studentov vuza $v$ protsesse obucheniia inostrannym iazykam: monografiia [Formation of SelfEducation Competence of the University Students in the Process of Studying and Learning Foreign Languages: Monograph]. Kazan, Iz-vo Otechestvo, 124 p. 
Smolyaninova, O.G. (2016a). Theory and Practice of Tolerance Development by Means of the Intercultural Educational Platform of Siberian Federal University: Collective Monograph. Krasnoyarsk, Siberian Federal University, 100 p.

Smolyaninova, O.G. (2016b). Intercultural Educational Platform and PL2S Center for Developing Tolerance of Krasnoyarsk Region Citizens: Proc. EDULEARN16 Conference. Barcelona, 1005-1013.

Smolyaninova, O.G. (2018). Mediation Practices in Education: Intercultural Contexts of Multinational Siberia. In Proc. 10th International Conference on Education and New Learning Technologies. Palma, Mallorca, 3862-3867.

Smolyaninova, O.G., Trufanov, D.O. (2018). "Double bottom" of Intercultural Competence: evaluation by means of electronic educational platform of a Federal University. In J. Sib. Fed. Univ. Humanit. soc. sci., 11(10), 1673-1698. DOI: 10.17516/1997-1370-0327.

Soldatova, G.U., Shaigerova, L.A., Prokof'eva, T.U., Kravtsova, O.A. (2008). Psikhodiagnostika tolerantnosti lichnsti [Psychodiagnostics of Personal Tolerance]. Moscow, Smysl, 172.

Tregubova, T.M. (2015). Mezhdunarodnye proekty polikul'turnogo obrazovaniia studentov v situatsii teoreticheskikh ugroz [The International Projects in the Field of Multicultural Education of Students in a Situation of Terrorist Threats], In Kazan Pedagogical Journal, 1, 48-53.

Tregubova, T.M. (2016). Mezhdunarodnoe sotrudnichestvo kak faktor integratsii rossiiskoi professional'noi shkoly v mirovoe obrazovatel'noe prostranstvo [International Cooperation as a Factor of Integration of Russian Professional School in the International Educational Environment]. In Sovremennoe professional'noe obrazovanie: problemy, prognozy, resheniia [Modern Professional Education: Problems, Perspectives, Solutions], 149-153.

Zainieva, L.U., Zikova, N.M., Ermakhanova, R.A., Kasimbaeva, T.N. (2015). Educational Aspect in the International Cooperation of Youth, In New Conceptions of Fundamental Research: Experience, Traditions, Innovations and Effective Strategy of Its Development, 55-57.

Zannoni, F., Cuconato, M., Tregubova, T.M., Maslennikova, V.Sh., Trufanov, D., Smolyaninova, O.N., Nidgereini, N., McKinney, S., Kholl, S. (2017). D 3.1 Recommendations on Management, Creation and Implementation. Kazan, Institute of Pedagogy and Professional Education, 31.

Zannoni, F., Kostrov, E.N. (2017). Promoting Tolerance and Intercultural Education in Russia. The Experience of the ALLMEET Intercultural Education Platforms. 
In Formirovanie grazhdanskoi identichnosti molodezhi v usloviiakh sotsial'noekonomicheskikh realii rossiiskogo obshchestva [Formation of Civil Identity of Youth in the Conditions of Socio-Economical Reality of Russian Society], 335-340.

Ziuban, A.V. (2014). Formirovanie edinogo obrazovatel'nogo prostranstva v ramkakh mezhdunarodnogo sotrudnichestva [Formation of a Unified Educational Space in the Framework of International Cooperation]. In Aktual'nye problemy ekonomiki i upravleniia [Actual Problems of Economy and Management], 3 (3), 68-71.

\title{
Дискурс по участию студентов в международных проектах по формированию межэтнической толерантности в поликультурном образовательном пространстве
}

\author{
T.М. Трегубова, В.Е. Козлов, А.С. Кац \\ Институт педагогики, психологии и сочиальных проблем \\ Россия, Республика Татарстан, 420039, Казань, ул. Исаева, 12
}

\begin{abstract}
Цель данной статьи - установить, насколько участие студентов в международньх образовательных проектах стимулирует развитие личностных, духовных и морально-нравственных качеств студентов, таких, например, как межэтническая толерантность, а также проанализировать характер, динамику и основные тенденции развития межэтнической толерантности в поликультурном образовательном пространстве. С точки зрения педагогической науки и практики участие в международных проектах рассматривается как уникальная возможность продемонстрировать присутствие этнической принадлежности в профессиональной и межличностной сферах общения, а также как значительное продвижение к межэтническому взаимодействию, основанному на принципах международного сотрудничества. Результать эмпирического исследования показали эффективность и продуктивность международных проектов как механизма личностного роста, развития и самосовершенствования. Основываясь на результатах проведенного исследования, удалось проследить перспективные пути развития международного сотрудничества российских вузов с европейскими партнерами в сфере образования. Подводя промежуточные итоги, хочется отметить, что международные проекты расширяют возможности образовательного прочесса, а также круг профессионального и межличностного общения и во многом способствуют формированию нового типа специалиста - личности с планетарным мышлением, обучающейся/работающей в условиях поликультурного образовательного пространства, творческой, гибкой и флексивной, умеющей приспосабливаться к динамичным изменениям все более глобализирующегося мира.
\end{abstract}

Ключевые слова: международный образовательный проект, международное сотрудничество, этничность, этническая группа, поликультурное образовательное пространство.

Научная специиальность: 13.00.00 - педагогические науки. 